\title{
PERKAWINAN DI BAWAH UMUR MENURUT HUKUM ISLAM DAN HUKUM POSITIF DI INDONESIA
}

\author{
Heppy Hyma Puspytasari \\ Dosen Prodi PPKN STKIP PGRI JOMBANG
}

heppyhyma@gmail.com

\begin{abstract}
ABSTRAK
Setelah ada perubahan Undang-Undang baru, yakni UU nomor nomor 16 tahun 2019 tentang perubahan atas UU RI nomor 1 tahun 1974 tentang perkawinan. Batas umur pria dan wanita disamakan. "Baik pria maupun wanita minimal harus sudah mencapai umur 19 tahun, Akan tetapi kenyataannya berbanding terbalik, banyak pasangan yang melakukan perkawinan di bawah umur. Menurut para sosiolog, ditinjau dari sisi sosial, pernikahan dini dapat mengurangi harmonisasi keluarga. Hal ini disebabkan oleh emosi yang masih labil, gejolak darah muda dan cara pikir yang belum matang. Melihat pernikahan dini dari berbagai aspeknya memang mempunyai banyak dampak negatif. Tujuan dari penulisan ini adalah untuk Untuk menjelaskan perkawinan di bawah umur menurut hukum Islam dan hukum positif di Indonesia dan untuk menjelaskan faktor penyebab perkawinan di bawah umur. Kesimpulan yang diperoleh adalah bahwa Menurut hukum Islam dan hukum Positif di Indonesia, bahwa perkawinan di bawah umur adalah perempuan usia di bawah 19 tahun dan laki-laki kurang dari 19 tahun, masih memberikan peluang untuk tetap melangsungkan perkawinan meskipun di bawah umur dengan mendapat izin dari orang tua, dan meminta dispensasi kepada Pengadilan Agama atau pejabat lain yang ditunjuk. Menurut hukum syariah (Islam) batasan baliq yang sesuai dengan hadist, yaitu: "baligh" atau dewasa dalam konteks fisik maupun mental sehingga seseorang mampu untuk melangsungkan perkawinan secara sehat dan bertanggung jawab. Faktor penyebab perkawinan di bawah umur, yaitu faktor internal meliputi kurang terpenuhinya kebutuhan pendidikan secara maksimal, lemahnya pengawasan dari orang tua, sedangkan faktor eksternal meliputi faktor ekonomi dan kemajuan teknologi komunikasi.
\end{abstract}

Kata Kunci : Perkawinan Dibawah Umur dan Hukum 


\section{IURNAL JENDELA HUKUM}

ISSN Cetak E Online : 2355-5831/ 2355-9934

\section{A. PENDAHULUAN}

Perkawinan adalah berkumpulnya dua insan yang semula terpisah dan berdiri sendiri, menjadi satu kesatuan yang utuh dan bermitra. Perkawinan merupakan suatu proses untuk membentuk sebuah keluarga antara seorang laki-laki dengan seorang perempuan yang didasari rasa cinta dan kasih sayang. Sedangkan menurut fiqh, sebagaimana disebutkan Soelaiman Rasyid, perkawinan adalah akad yang menghalalkan pergaulan dan membatasi hak dan kewajiban serta tolong menolong antara seorang laki-laki dan seorang perempuan yang bukan mahramnya. ${ }^{1}$

Perkawinan yang ideal adalah perkawinan yang berlangsung abadi atau kekal walau tidak tertutup kemungkinan untuk putus atau diputuskan. Untuk itu perkawinan memerlukan kematangan mental dan psikologis dari kedua pasangan. Untuk kemaslahatan keluarga dan rumah tangga pernikahan hanya boleh dilakukan calon mempelai yang telah mencapai umur yang ditetapkan dalam pasal 7 UU No. 1 Tahun 1974.

Menurut kitab Undang-Undang hukum perdata perkawinan tidak boleh dilakukan jika seorang jejaka yang belum mencapai umur genap delapan belas tahun (18), seperti pun seorang gadis yang belum

1 Soelaiman Rasyid, Fiqh Islam, Jakarta: Attahiriyah, 1997, h. 374 mencapai umur genap lima belas tahun (15), tidak diperbolehkan mengikat dirinya dalam perkawinan. ${ }^{2}$

Dalam Undang-undang Perkawinan bab II pasal 7 ayat 1 disebutkan bahwa perkawinan hanya diizinkan jika pihak pria mencapai umur 19 (sembilan belas) tahun dan pihak perempuan sudah mencapai umur 16 (enam belas tahun) tahun. Meski UU nomor 16 tahun 2016 tentang perubahan atas UU RI nomor 1 tahun 1974 tentang perkawinan sudah disahkan, angka perkawinan anak di bawah umur masih tinggi. Hal ini bisa terlihat dari angka permohonan dispensasi kawin. Kenaikan jumlah pemohon dispensasi, salah satunya usai disahkannya UU baru tentang perkawinan. Jika mengacu UU nomor 1 tahun 1974, batas umur pria boleh menikah minimal sudah berumur 19 tahun, sementara umur pengantin wanita dibatasi minimal 16 tahun.

Setelah ada perubahan UU baru, yakni UU nomor nomor 16 tahun 2019 tentang perubahan atas UU RI nomor 1 tahun 1974 tentang perkawinan. Batas umur pria dan wanita disamakan. "Baik pria maupun wanita minimal harus sudah mencapai umur 19 tahun, Akan tetapi kenyataannya berbanding terbalik, banyak pasangan yang melakukan

\footnotetext{
${ }^{2}$ KUHPerdata
} 
perkawinan di bawah umur.

Dari kedua peraturan perundangan tersebut meskipun terjadi perbedaan dalam pembatasan usia, peraturan ini bertujuan untuk melindungi kepentingan dan hak-hak anak dan definisi anak di sini adalah dibawah 18 tahun. $^{3}$

Anak jika melakukan pernikahan dikhawatirkan mempunyai dampak negatif baik bagi ibu maupun anak yang dilahirkan, dampak negatif lainnya adalah kesehatan reproduksi wanita menjadi terganggu. Menurut para sosiolog, ditinjau dari sisi sosial, pernikahan dini dapat mengurangi harmonisasi keluarga. Hal ini disebabkan oleh emosi yang masih labil, gejolak darah muda dan cara pikir yang belum matang. Melihat pernikahan dini dari berbagai aspeknya memang mempunyai banyak dampak negatif. Oleh karenanya, pemerintah hanya mentolerir pernikahan di atas umur 19 tahun. $^{4}$

\section{B. PEMBAHASAN}

\section{Perkawinan di Bawah Umur}

\section{Menurut Hukum Positif di Indonesia}

Pengaturan hukum tentang perkawinan telah berlaku sama terhadap semua warga negara oleh karena itu, setiap warga negara harus patuh terhadap hukum yang berlaku, termasuk terhadap undangundang perkawinan yang menjadi landasan

\footnotetext{
${ }^{3}$ UU Perlindungan anak

${ }^{4}$ UU Perkawinan jo perubahan nya UU No. 16 Tahun 2019
}

untuk menciptakan kepastian hukum, baik dari sudut hukum keluarga,harta, bendadan akibat hukum suatu perkawinan. $^{5}$

Menurut Pasal 1 Undang-Undang Nomor 1 Tahun 1974 tentang Perkawinan menyebutkan bahwa perkawinan adalah ikatan lahir bathin antara seorang pria dan seorang wanita sebagai suami-isteri dengan tujuan membentuk keluarga atau rumah tangga yang bahagia dan kekal berdasarkan Ketuhanan Yang Maha Esa. ${ }^{6}$

Sejak di undangkan Hukum negara yang mengatur mengenai masalah perkawinan adalah Undang-undang Nomor 1 Tahun 1974 tentang Perkawinan. Untuk dapat mewujudkan tujuan perkawinan, salah satu syaratnya adalah bahwa para pihak yang akan melakukan perkawinan telah matang jiwa dan raganya. Oleh karena itu di dalam Undang-undang Nomor 1 Tahun 1974 ditentukan batas umur minimal untuk melangsungkan perkawinan. Ketentuan mengenai batas umur minimal tersebut terdapat di dalam Bab II Pasal 7 ayat (1) Undang-undang Nomor 1 Tahun 1974 yang mengatakan bahwa "Perkawinan hanya diizinkan jika pihak pria sudah

5 Wajik Saleh, Hukum Perkawinan Indonesia, (Jakarta: Ghalia Indonesia, Jakarta, 1982), h.3

6 Rahmatiah, Studi kasus Perkawinan di Bawah umur, Al-Daulah Vol. 5 / No. 1 / Juni 2016, h. 3 
mencapai usia 19 tahun dan pihak wanita sudah mencapai usia 16 tahun". Dari adanya batasan usia ini dapat ditafsirkan bahwa Undang-undang Nomor 1 Tahun 1974 tidak mengehendaki pelaksanaan perkawinan di bawah umur. ${ }^{7}$

Apabila ada perkawinan yang dilakukan oleh anak usia di bawah umur dalam hal ini pemerintah memberikan Kebijakan dalam menetapkan batas minimal usia pernikahan yang tentunya melalui proses dan berbagai pertimbangan atau lazim disebut sebagai dispensasi. Hal ini dimaksudkan agar kedua belah pihak benar-benar siap dan matang dari sisi fisik, psikis dan mental untuk melakukan perkawinan, karena mengigat perkawinan yang dilakukan agar kelak dapat terbina kekal abadi berdasarkan kepada Ketuhanan Yang Maha Esa sampai hayat memisahkan ke duanya serta untuk menunjang program kependudukan. ${ }^{8}$

Tidak semua pengajuan dispensasi pernikahan di bawah umur dapat dikabulkan oleh Pengadilan Agama. Pengajuan dispensasi dapat ditolak dengan alasan kedua calon mempelai masih terlalu dini melakukan pernikahan karena dianggap

7 UU Perkawinan, demikian juga dalam UU No. 16 Tahun 2019 tentang pembaharuan UU Perkawinan menyatakan bahwa Perkawinan hanya diizinkan apabila pria dan wanita sudah mencapai umur 19 (sembilan belas) tahun.

${ }^{8}$ Zulfiani, Kajian hukum terhadap Perkawinan anak dibawah Umur menurut undang-undang nomor 1 tahun 1974, jurnal Hukum Samudra Keadilan, Volume 12, Nomor 2, Juli-Desember 2017. masih kanak-kanak dan belum terjadi kecelakaan (hamil duluan) dan apabila permohonan dispensasi tersebut tetap dikabulkan dikhawatirkan apabila sudah berumah tangga tidak akan bisa harmonis karena belum ada kesiapan mental dan psikologis. $^{9}$

Pengajuan dispensasi dapat diterima oleh Pengadilan Agama dengan dasar alasan apabila sudah terjadi kecelakaan (hamil duluan). Penerimaan dispensasi ini bertujuan untuk melindungi hak anak dari hasil hubungan di luar perkawinan. Hak anak yang dilindungi antara lain untuk mempermudah dalam pengurusan segi administrasi secara hukum misalnya saja akte kelahiran sehingga memperjelas status hukum dari anak tersebut. Dan hak anak yang dilindungi dalam jangka panjang adalah tentang masalah ke warisan.

Hukum Islam tidak ada batasan usia dalam melakukan suatu perkawinan. Islam memandang suatu pernikahan dikatakan sah bukan atas dasar usia akan tetapi atas dasar sudah terpenuhi rukun dan syarat perkawinan yaitu adanya wali dan dua orang saksi, serta mahar dan akad pengantin itu sendiri sudah sah menurut Islam. Pernikahan merupakan suatu perkara yang disunahkan apabila ada

${ }^{9}$ CST. Kansil, Pengertian Ilmu Hukum dan Tata Hukum Indonesia, (Jakarta : Balai Pustaka, 1989), h.. 230 
kesiapan dan restu orang tua maka pernikahan tersebut lebih baik cepat dilaksanakan. Pernikahan dipercepat dengan tujuan untuk menghindari suatu perbuatan yang tidak diinginkan misalnya saja "seks bebas".

Rasullulah SAW. sendiri pernah melakukan pernikahan di bawah umur saat menikahi istrinya yaitu Siti Aisyah yang masih berusia 7 tahun dan baru dikumpuli oleh Rosullulah pada usia 9 tahun. Belajar dari cerita Rosullulah maka dapat diambil hikmah bahwa meskipun terjadi pernikahan di bawah umur maka diperlukan pengertian antar kedua pasangan suami istri tersebut. Hal tersebut bertujuan untuk menunggu kesiapan organ reproduksi agar dapat berfungsi secara maksimal "menunggu baligh". ${ }^{10}$

Dalam hal pernikahan di bawah umur, baik itu diistilahkan sebelum haid, dalam pandangan Islam sah, yang pandangan telah telah sepakat, bahwa seorang ayah yang menikahkan anak gadisnya yang masih kecil hukumnya mubah (sah). ${ }^{11}$

Usia perkawinan dalam pemikiran hukum Islam hanya dipersyaratkan telah mencapai baligh antara kedua calon suami isteri, inheren dengan syarat-syarat dan rukun perkawinan. Salah satu syarat sah

\footnotetext{
${ }^{10}$ Zulfiani, op.cit h. 213

${ }^{11}$ http://konsultasi.wordpress.com/2008/11/22/h ukum-menikahi-perempuan-di-bawa-umur/\#more331(ditulis oleh : Farid marid ma'ruf, 22 November 2008).
}

perkawinan adalah mencapai usia baligh, sehingga secara tegas harus memenuhi ketentuan hukum Islam yang sesuai dengan ketentuan pasal 2 ayat (1) Undang-Undang No. 1 tahun 1974 tentang Perkawinan. ${ }^{12}$

Adapun ayat yang berkaitan dengan kelayakan seseorang untuk menikah ada dalam al-Quran, yaitu Q.S. Al-Nur Ayat 32 dan Q.S. An-Nisa' ayat 6. Dalam tafsir al-misbah, makna kata dasar rushdan dalah ketepatan dankelurusan jalan. Dari sini lahir kata rushd yang bagi manusia adalah kesempurnaan akal dan jiwa yang menjadikannya mampu bersikap dan bertindak setepat mungkin. Al-Maraghi menafsirkan dewasa (rushdan), yaitu apabila seseorang mengerti dengan baik cara menggunakan harta serta memebelanjakannya, sedang yang dimaksud balighu al-nikdh ialah jika umur telah siap untuk menikah. Ini artinya al-Maraghi menginterpretasikan bahwa orang yang belum dewasa tidak boleh dibebani persoalan-persoalan tertentu. $^{13}$

Pada zaman sekarang ini banyak terjadi pernikahan di bawah umur dilangsungkan bukan karena adanya suatu kesiapan atau niatan ibadah untuk

${ }^{12}$ Andi Syamsu Alam, Usia Ideal Memasuki Dunia Perkawinan (Jakarta:Kencana Mas,1990)

${ }^{13}$ Udma Laela, Perkawinan di bawah umur ditinjau dari hukum islam dan Hukum Adat di Desa Tanah Towa Kecamatan Kajang kabupaten Bulukumba, h. 56. 
melangsungkan suatu pernikahan, akan tetapi pernikahan di bawah umur terjadi atas dasar suatu keterpaksaan karena banyak terjadinya pergaulan bebas "seks bebas".

Pernikahan tersebut dilangsungkan bertujuan untuk menutupi "aib keluarga" (hamil duluan). Dan apabila tidak dinikahkan akan menjadi suatu masalah dan beban sosial dalam masyarakat. Anak hasil hubungan di luar nikah tidak akan jelas status hukumnya dan status keturunannya apabila tidak memiliki orang tua yang jelas dalam suatu ikatan perkawinan yang sah dan diakui secara hukum di Indonesia.

Untuk mencegah pernikahan di bawah umur untuk itu perlu ditanamkan pendidikan yang benar tentang suatu pernikahan. Pernikahan bukan hanya sekedar masalah melakukan hubungan suami istri akan tetapi ada hak dan kewajiban yang perlu dijalankan seseorang ketika berumah tangga. Untuk menjalankan hak kewajiban itu perlu adanya saling pengertian dan saling menghormati antara suami dan istri dalam berumah tangga misalnya saja kewajiban suami untuk mencari nafkah dan kewajiban untuk mendidik anak-anaknya kelak.

1. Faktor Penyebab Perkawinan di Bawah Umur.

Dalam perkawinan di bawah umur tentu saja banyak faktor faktor yang menjadi penyebab untuk melangsungkan sebuah perkawinan, baik faktor internal maupun faktor eksternal.

\section{a. Faktor Internal}

1. Kurang Terpenuhi Kebutuhan Pendidikan

Perkawinan di bawah umur terjadi karena keluarga tidak bisa memenuhi kebutuhan secara maksimal kepada anaknya. Salah satunya adalah kebutuan tentang pendidikan. Jika keluarga mampu memberikan pendidikan secara maksimal kepada anak maka secara tidak langsung akan mengurangi keinginan untuk menikah di usia muda baik keinginan dari orang tua maupun keinginan anak. Hal itu terjadi karena seorang anak mempunyai tanggung jawab untuk menyelesaikan pendidikan. Apabila seorang anak kebutuhan akan pendidikan dapat terpenuhi secara maksimal maka tidak akan ada kesempatan untuk menikah muda atau menikah di bawah umur. ${ }^{14}$ Pendidikan merupakan salah satu faktor yang mempengaruhi persepsi seseorang,dengan pendidikan tinggi seseorang akan lebih mudah menerima atau memilih suatu perubahan yang lebih baik. $^{15}$

${ }^{14}$ Siti Yuli Astuti, Faktor-faktor Penyebab Terjadinya Perkawinan Usia Muda di Kalangan Remaja di desa Tembung Kecamatan Percut Sei Tuan Kabupaten Deli Serdang, h. 6.

${ }^{15}$ Suprapto,A., Pradono, J. dan Hapsari, D. 2004. Determinan sosial ekonomi pada pertolongan persalinan di Indonesia. Majalah Kedokteran Perkotaan.Vol 2, no. 2, pp.18-29. 
2. Kurang Pengawasan Terhadap Anak

Perkawinan di bawah umur terjadi karena kelalaian orang tua dalam mendidik dan mengawasi anak-anak mereka. Kurangnya pengawasan orang tua dikarenakan orang tua jarang di rumah dengan alasan aktifitas pekerjaan. Dengan kondisi yang kurang pengawasan dari orang tua seorang anak menjadi leluasa untuk melakukan hal apapun bahkan perilaku yang terlalu bebas hal tersebut terjadi karena berbagai kemajuan bidang teknologi. Seorang anak yang masih remaja apabila lemah pengawasan dan tidak diarahkan oleh orang tua atau keluarga dikhawatirkan akan menyebabkan perilaku menyimpang apabila salah dalam pergaulan.

Untuk mencegah pernikahan di bawah umur maka diperlukan peran aktif keluarga untuk menanamkan nilai-nilai religius keagamaan kepada anaknya sebagai benteng dari berbagai kemajuan zaman yang ada, agar mereka terhindar dari pergaulan bebas atau seks bebas. Orang tua diharapkan mampu untuk meluangkan waktu bagi anaknya sebagai bentuk perhatian dan pengawasan terhadap perkembangan akademis dan perkembangan pergaulan anaknya. ${ }^{16}$

16 Munawwaroh, Siti. "Studi Terhadap Pernikahan Usia Dini di Kecamatan Seberang Ulu I Kota Palembang Ditinjau dari Hukum Islam', Intelektualita, Volume 5, Nomor 1, Juni 2016, hlm.

\section{b. Faktor Eksternal}

1. Ekonomi

Pada beberapa wilayah, ketika kemiskinan benar-benar menjadi permasalahan yang sangat mendesak, perempuan muda sering dikatakan sebagai beban ekonomi keluarga. Oleh karenanya perkawinan usia muda dianggap sebagai suatu solusi untuk mendapatkan mas kawin dari pihak lakilaki untuk menganti seluruh biaya hidup yang telah dikeluarkan oleh orangtuanya. ${ }^{17}$

2. Media massa

Globalisasi dan kemajuan teknologi merupakan suatu hal yang tidak dapat dihindari oleh semua kalangan masyarakat. Salah satu dampak buruk dari kemajuan teknologi komunikasi adalah maraknya pergaulan bebas "seks bebas". Kemudahan untuk memperoleh informasi dan berhubungan dengan orang lain sering disalahgunakan oleh kalangan anak remaja untuk mengakses atau mendapatkan berbagai konten yang bermuatan negatif. $^{18}$

38, online pada http :// jurnal .radenfatah.ac.id/ index.php/intelektual/article/view/723/648

17 Anonim. 2000. Perkawinan Usia Dini Berisiko Tinggi Bagi Perempuan. Diakses dari http://www.Kompas.com.

${ }^{18}$ Hotnatalia Naibaho, Faktor-faktor yang mempengaruhi Pernikahan Usia Muda ( Studi Kasus di Dusun IX Seroja Pasar VII Tembung Kecamatan Percut Sei Tuan kabupaten Deli Serdang), h. $\quad 10$ https://media.neliti.com/media/publications/22206 3-faktor-faktor-yang-mempengaruhi-pernikah.pdf 
Untuk itu diperlukan pengawasan dari orang tua, masyarakat dan lingkungan sekolah. Pengawasan tersebut dapat berupa pembatasan pemakaian teknologi informasi komunikasi agar secara tidak langsung upaya mereka untuk mengakses hal-hal yang bersifat negatif dapat dibatasi juga. Orang tua juga diharapkan untuk mampu mengikuti perkembangan zaman "tidak Gaptek" agar tidak mudah dibohongi oleh anaknya dalam pemakaian teknologi informasi dan komunikasi.

Sekolah juga diharapkan mampu untuk menanamkan pendidikan yang berarakter dengan menyeimbangkan kepentingan akademis dan kepentingan religius untuk menciptakan generasi-generasi mudah yang tidak hanya cerdas secara akademis tetapi juga cerdas religius dan sosial. Selain peran serta orang tua, sekolah peran dan dukungan masyarakat juga sangat diperlukan. Masyarakat hendaknya ikut juga mengawasi pergaulan anak-anak remaja yang ada di lingkungannya sekitar agar anak-anak remaja tidak memiliki kesempatan untuk melakukan hal-hal yang bersifat negatif.

Peran aktif keluarga juga sangat diperlukan untuk menanamkan nilai-nilai religius keagamaan kepada anaknya sebagai benteng dari berbagai kemajuan zaman yang ada, agar mereka terhidar dari pergaulan bebas atau seks bebas. Orang tua diharapkan mampu untuk meluangkan waktu bagi anaknya sebagai bentuk perhatian dan pengawasan terhadap perkembangan akademis dan perkembangan pergaulan anaknya.

Untuk mencegah perkawinan di bawah umur untuk itu perlu ditanamkan pendidikan yang benar tentang suatu perkawinan. Perkawinan bukan hanya sekedar masalah melakukan hubungan suami istri akan tetapi ada hak dan kewajiban yang perlu dijalankan seseorang ketika berumah tangga. Untuk menjalankan hak kewajiban itu perlu adanya saling pengertian dan saling menghormati antara suami dan istri dalam berumah tangga, misalnya saja kewajiban suami untuk mencari nafkah dan kewajiban untuk mendidik anak-anaknya kelak.

Diperlukan adanya kerjasama dari berbagai pihak untuk melakukan pengawasan dan penyuluhan dari berbagai elemen masyarakat tentang bahaya pergulan bebas "seks bebas" sehingga secara tidak langsung dapat mengurangi perkawinan di bawah umur.

\section{KESIMPULAN}

1. Kesimpulan

Menurut hukum Islam dan hukum Positif di Indonesia, bahwa perkawinan di bawah umur adalah perempuan usia di bawah 19 tahun dan laki-laki kurang dari 19 tahun, masih memberikan peluang untuk tetap melangsungkan perkawinan 
meskipun di bawah umur dengan mendapat izin dari orang tua, dan meminta dispensasi kepada Pengadilan Agama atau pejabat lain yang ditunjuk oleh kedua orang tua baik pihak pria maupun pihak wanita, dengan dasar alasan apabila sudah terjadi kecelakaan atau hamil duluan. Penerimaan despensasi ini bertujuan untuk melindungi hak anak. Menurut hukum syariah (Islam) tidak ada batasan usia dalam melakukan suatu perkawinan kecuali batasan baliq yang sesuai dengan hadist, yaitu: "baligh" atau dewasa dalam konteks fisik dan mental, sehingga seseorang mampu untuk melangsungkan perkawinan secara sehat dan bertanggung jawab.

Faktor penyebab perkawinan di bawah umur, yaitu faktor internal meliputi kurang terpenuhinya kebutuhan pendidikan secara maksimal, lemahnya pengawasan dari orang tua, sedangkan faktor eksternal meliputi faktor ekonomi dan kemajuan teknologi komunikasi

\section{Saran}

Berdasarkan hasil kajian dan uraian di atas, akan dikemukakan beberapa saran berkaitan adalah sebagai berikut :

1. Untuk mencegah perkawinan di bawah umur maka diperlukan peran aktif keluarga untuk menanamkan nilai-nilai religius keagamaan kepada anaknya sebagai benteng dari berbagai kemajuan zaman yang ada, agar mereka terhidar dari pergaulan bebas atau seks bebas.
Orang tua diharapkan mampu untuk meluangkan waktu bagi anaknya sebagai bentuk perhatian dan pengawasan terhadap perkembangan akademis dan perkembangan pergaulan anaknya.

2. Untuk mencegah perkawinan di bawah umur untuk itu perlu ditanamkan pendidikan yang benar tentang suatu perkawinan. Perkawinan bukan hanya sekedar masalah melakukan hubungan suami istri akan tetapi ada hak dan kewajiban yang perlu dijalankan seseorang ketika berumah tangga. Untuk menjalankan hak kewajiban itu perlu adanya saling pengertian dan saling menghormati antara suami dan istri dalam berumah tangga, misalnya saja kewajiban suami untuk mencari nafkah dan kewajiban untuk mendidik anak-anaknya kelak.

\section{DAFTAR BACAAN}

\section{A. Buku}

Andi Syamsu Alam, Usia Ideal Memasuki Dunia Perkawinan (Jakarta:Kecana Mas,1990)

CST. Kansil, Pengertian Ilmu Hukum dan Tata Hukum Indonesia, (Jakarta : Balai Pustaka, 1989), h.. 230

Soelaiman Rasyid, Fiqh Islam, (Jakarta: Attahiriyah, 1997), h. 374.

Peter Mahmud Marzuki. Peter Mahmud Marzuki,Penelitian Hukum, Kencana Prenada Media Group, Jakarta, 2011, h. 32 . 
Soerjono Soekanto, dan Sri Mamudji, Penelitian Hukum Normatif, Cetakan ke-8, PT. Raja Grafindo Persada, Jakarta, 2004, h. 14

K. Wajik Saleh, Hukum Perkawinan Indonesia, (Jakarta: Ghalia Indonesia, Jakarta, 1982), h.3

Rahmatiah, Studi kasus Perkawinan di Bawah umur, Al-Daulah Vol. 5 / No. 1 / Juni 2016

Zulfiani, Kajian hukum terhadap Perkawinan anak dibawah Umur menurut undang-undang nomor 1 tahun 1974, jurnal Hukum Samudra Keadilan, Volume 12, Nomor 2, JuliDesember 2017

Suprapto,A., Pradono, J. dan Hapsari, D. 2004. Determinan sosial ekonomi pada pertolongan persalinan di Indonesia. Majalah Kedokteran Perkotaan.Vol 2, no. 2, pp.18-29. http://konsultasi.wordpress.com/2008/ 11/22/hukum-menikahi-perempuandi-bawa-umur/\#more-331(ditulis oleh:farid marid ma'ruf, 22 November 2008)

Siti Yuli Astuti, Faktor-faktor Penyebab Terjadinya Perkawinan Usia Muda di Kalangan Remaja di desa Tembung Kecamatan Percut Sei Tuan Kabupaten Deli Serdang,h. 6, https://media.neliti.com/media/public ations/222008-faktor-faktorpenyebab-terjadinya-perkaw.pdf

Munawwaroh, Siti. "Studi Terhadap Pernikahan Usia Dini di Kecamatan Seberang Ulu I Kota Palembang Ditinjau dari Hukum Islam', Intelektualita, Volume 5, Nomor 1, Juni 2016, hlm. 38, online pada http :// jurnal .radenfatah.ac.id/ index.php/intelektual/article/view/723 1648

Anonim. 2000. Perkawinan Usia Dini Berisiko Tinggi Bagi Perempuan. Diakses dari http://www.Kompas.com.

Hotnatalia Naibaho, Faktor-faktor yang mempengaruhi Pernikahan Usia Muda ( Studi Kasus di Dusun IX
Seroja Pasar VII Tembung Kecamatan Percut Sei Tuan kabupaten Deli Serdang), h. 10 https://media.neliti.com/media/publ ications/222063-faktor-faktor-yangmempengaruhi-pernikah.pdf https://radarjombang.jawapos.com/r ead/2020/01/07/173633/pernikahan -dini-di-jombang-semakin-tinggisetahun-tembus-183-pemohon

Udma Laela, Perkawinan di bawah umur ditinjau dari hukum islam dan Hukum Adat di Desa Tanah Towa Kecamatan Kajang kabupaten Bulukumba, h. $\quad 56$ ,http://repositori.uinalauddin.ac.id/7489/

\section{B. Undang-Undang}

Kitab Undang-Undang Hukum Perdata

Undang-Undang No. 35 Tahun 2014

Tentang Perlindungan anak

Undang-Undang Perkawinan jo perubahan nya Undang-Undang No. 16 tahun 2019 